\title{
Surface Contamination of Titanium by Abrading Treatment
}

\author{
Osamu MIYAKAWA, Kouichi WATANABE, Seigo OKAWA, Mitsugu KANATANI, \\ Syuji NAKANO and Masayoshi KOBAYASHI ${ }^{1}$ \\ Department of Dental Materials and Technology, Niigata University School of Dentistry, \\ ${ }^{1}$ EMX Laboratory, Niigata University, \\ Gakkoucho-dori, 2-5, 274, Niigata 951, Japan
}

Received December 14, 1995/Accepted April 18, 1996

This study investigated the contamination of abraded Ti surfaces. Using a polishing machine, specimens
were abraded with waterproof $\mathrm{SiC}$ grit papers under water cooling. The abraded surfaces were examined
using element analysis, $\mathrm{X}$-ray diffraction, and hardness tests. Contaminant deposits with dimensions
reaching about $30 \mu \mathrm{m}$ were observed throughout the surface. In these deposits, Ti was apparently reduced
by about $10 \%$ and replaced by $\mathrm{Si}$ and $\mathrm{O}$. The chemical bond state of the $\mathrm{Si}$ was similar to that of $\mathrm{SiC}$ or
a titanium silicide. The $\mathrm{O}$ was solute in Ti, which increased the surface hardness. The contaminant
deposits were amorphous or very thin. The contamination of Ti, the extent of which was related to
hardness, resulted from a reaction with abrasives.

Key words: Titanium, Abrasive, Surface contamination

\section{INTRODUCTION}

Titanium is known for its high resistance to corrosion and its excellent bio-compatibility. On the other hand, the metal has a high melting point and remarkable chemical reactivity at high temperatures. This makes titanium casting difficult, but the recent development of investment materials and casting machines has enabled clinical applications of titanium in dentistry.

There remain several problems to be solved. First of all, efficient finishing techniques are required. Tianium is a difficult-to-grind metal, because of its plasticity, stickiness, low heat conductivity, and chemical reactivity at high temperatures. However, the number of studies concerning this problem is extremely limited, compared with those treating investment materials, casting machines and casting techniques. Regarding this problem, the authors have previously reported that high speed grinding results in both the chemical wear of abrasive grit and the burn, or discoloration and contamination, of the surface, and that this tendency is promoted by heavy grinding loads ${ }^{1,2}$.

The present study concerns the surface contamination of abraded titanium. Despite low grinding speeds and water cooling, the abraded surfaces were found to be contaminated by abrasive constituent elements. Element analysis and chemical bond state analysis of the contaminants were performed using an electron probe microanalyzer. X-ray diffraction of the abraded surface was performed to identify the contaminants. The results revealed that the contamination of titanium is related to its reactivity as well as its hardness. 


\section{MATERIALS AND METHODS}

\section{Preparation of specimens}

Cast plates were prepared for the present study. A wax sheet of $1.4 \times 16 \times 18 \mathrm{~mm}$ was invested using a phosphate-bonded silica or a magnesia-based investment for titanium casting. The casting mold was burned out according to the manufacturers' instructions. Using a titanium casting machine, a titanium ingot* equivalent to JIS class $2^{3)}$ was cast in the mold.

For comparison, a cast plate of type I dental gold alloy** was prepared using ordinary casting procedures.

\section{Abrading and polishing}

Before abrading and polishing, the specimens were resin-embedded or attached to a resin block with an adhesive. Specimens to be embedded were set by a clipping band made of 18 -8 stainless steel and pressed together with a resin powder in a vessel held at about $140^{\circ} \mathrm{C}$ for 15 min.

Using a polishing machine ${ }^{\#}$ for metallurgical structure observation, the resin-embedded and resin-attached specimens were abraded with waterproof silicon carbide abrasive papers to \#600 or 1,000 grit under water cooling. Fresh papers were used for each specimen. Subsequently, one of the specimens was polished with a buffing cloth on which an aqueous slurry of $\mathrm{Fe}_{2} \mathrm{O}_{3}$ powder was applied. Rotation speeds of the paper or cloth and the specimen were 130 and $50 \mathrm{rpm}$, respectively. During abrading and polishing, the specimen was subject to pressure from a spring. This was not quantified, but careful attention was paid to keep this pressure as constant as possible.

\section{Examination and analysis}

After some of the specimens were carbon-evaporated, distributions of titanium, silicon, iron, chromium, calcium, oxygen, and carbon were analyzed using an electron probe microanalyzer\#\#. The element analyses were performed in stage scan mode under the following condition : accelerating voltage $=20 \mathrm{kV}$, specimen current $=0.2 \mu \mathrm{A}$, step interval $=1 \mu \mathrm{m} / \mathrm{step}$, and measuring interval $=0.05 \mathrm{~s} / \mathrm{step}$. Besides the ordinary spectroscopic crystals such as LiF, PET and RAP, an artificially-prepared spectroscopic crystal, LSA ${ }^{\circledR}$, was used to detect oxygen and carbon with a sensitivity of perhaps 10 times or more. The oxygen $\mathrm{K} \alpha$ and the carbon $\mathrm{K} \alpha$ signals, whose backgrounds were liable to be elevated by coexistence with other elements, were processed through the pulse height selector.

The chemical bond states of silicon and oxygen on the abraded surface were determined by measuring their characteristic X-ray profiles ${ }^{4)}$. The profile of the silicon satellite $\mathrm{K} \alpha_{3,4}$ spectra of the unknown contaminant was compared with those of silica (quartz), silicon

* Pure Titanium A, Morita Co. Ltd., Kyoto, Japan

** Casting Gold Alloy M. C. type I, GC Co. Ltd., Tokyo, Japan

\# AUTOMAX, Refine Tec, Yokohama, Japan

\# EPMA-8705, Shimadzu Co. Ltd., Kyoto, Japan

@ Layered structure analyzer, Shimadzu Co. Ltd., Kyoto, Japan 
carbide, a titanium silicide-like phase ${ }^{4)}$, and silicon. The profile of the oxygen $\mathrm{K} \alpha$ spectrum of the contaminant was compared with those of the adhesive used in the abrasive paper, silica (quartz), titania (rutile), and a solute oxygen ${ }^{4}$ in titanium.

Using an X-ray diffractometer ${ }^{\circledR}$, a qualitative identification of the contaminant was attempted by the Bragg-Brentano method. Copper target and graphite monochromator were used under a power of $50 \mathrm{kV}$ and $300 \mathrm{~mA}$. Under a slit system (DS and $\mathrm{SS}=1^{\circ}$ and $\mathrm{RS}=0.30 \mathrm{~mm}$ ), the specimen was scanned at a speed of $4^{\circ} / \mathrm{min}$ and an interval of $0.02^{\circ}$.

The influence of the contaminant oxygen on the hardness of the abraded surface was investigated using a Vickers hardness (Hv) tester ${ }^{\$}$. The measuring load was $100 \mathrm{gf}$ and the load holding time was $15 \mathrm{~s}$.

\section{RESULTS AND DISCUSSION}

\section{Beginning of the problem}

Fig. 1 shows a secondary electron (SE) image of the abraded section of a titanium casting and the corresponding maps of oxygen and phosphorus. The line analysis profile of oxygen distribution along the line $\mathrm{AB}$ in the $\mathrm{SE}$ image was added to this figure for a semi-quantitative evaluation. The specimen was a casting from a phosphate-bonded silica investment mold. The bright vertical band seen in the oxygen and the phosphorus maps corresponds to the mold-metal interface. A reaction zone ${ }^{4)}$ with a width of one hundred $\mu \mathrm{m}$ or more is observed to the right of the band. The layer between the interface and a layer with a phosphorus-rich phase (indicated by arrow heads) is the so-called oxygen-stabilized $\alpha$-case. It has been widely documented that the solute oxygen content is highest near the mold-metal interface and decreases rapidly toward the interior of a casting ${ }^{4}$. However, Fig. 1 exhibits a remarkable increase and variation in oxygen content, starting from the layer with the phosphorus-rich phase and progressing toward the interior of casting ; this is entirely inconsistent with previous reports.

In prior studies, our specimen preparation for element analysis included abrading with waterproof silicon carbide grit papers, polishing with an aqueous slurry of $\mathrm{Fe}_{2} \mathrm{O}_{3}$ powder, and etching with a $5 \% \mathrm{HF}-20 \% \mathrm{HNO}_{3}$ aqua ${ }^{4,5)}$. The etching treatment serves to reveal the correspondence of element distributions and microstructure in the reaction zone, but might to some extent modify the element distributions, oxygen in particular. In order to escape the influence of etching, abraded unetched specimens were analyzed to obtain the data in Fig. 1. The higher oxygen content in the interior of the casting than in the reaction zone, probably from surface contamination, was obviously related to the abrading treatment.

\section{Surface contamination of abraded titanium}

The element analysis of the interior far from the reaction zone was performed at a higher magnification. Fig. 2 shows an SE image and the corresponding maps of titanium and oxygen. Areas with low titanium contents and high oxygen contents were observed overall, providing dappled and reversely dappled patterns in these element maps. For a semi-

@ @ (1) RINT-2500, Rigaku Corp., Tokyo, Japan

\$ MVK, Akashi Co. Ltd., Tokyo, Japan 

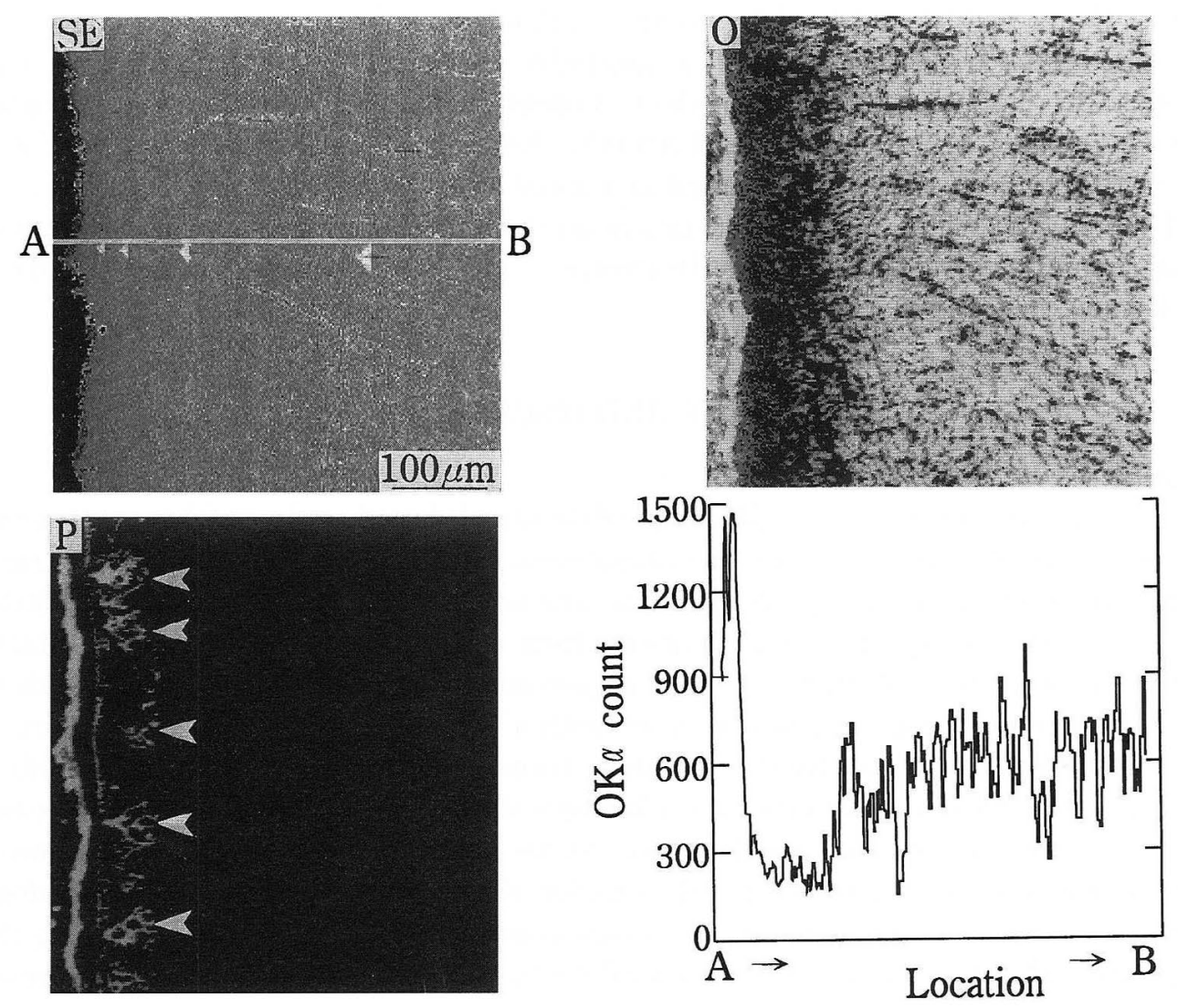

Fig. 1 Element distributions in the reaction zone of a Ti casting abraded to $\# 1,000$ grit. The line analysis profile shows the oxygen distribution along the line AB. The four marks along the line $\mathrm{AB}$ are Vickers hardness test indentations.

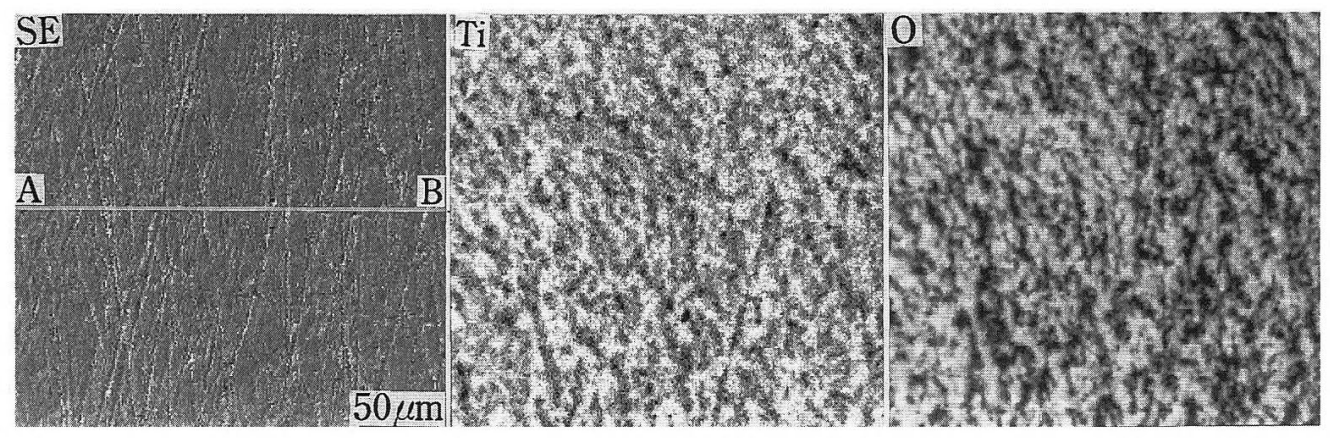

Fig. 2 Element distributions on an abraded Ti surface. Together with an 18-8 stainless steel chipping band, the specimen was resin-embedded and abraded to $\# 1,000$ grit. 

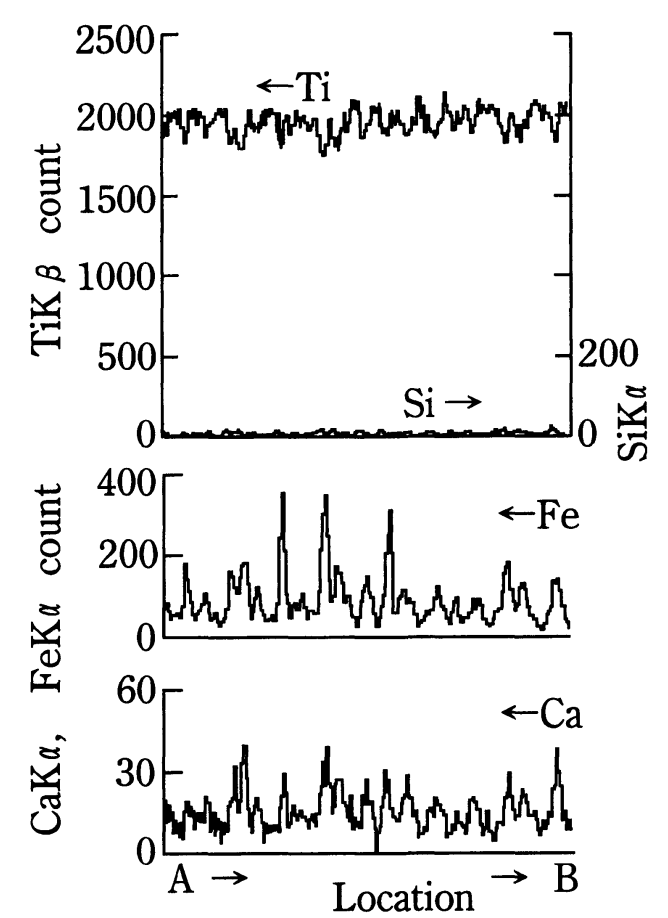
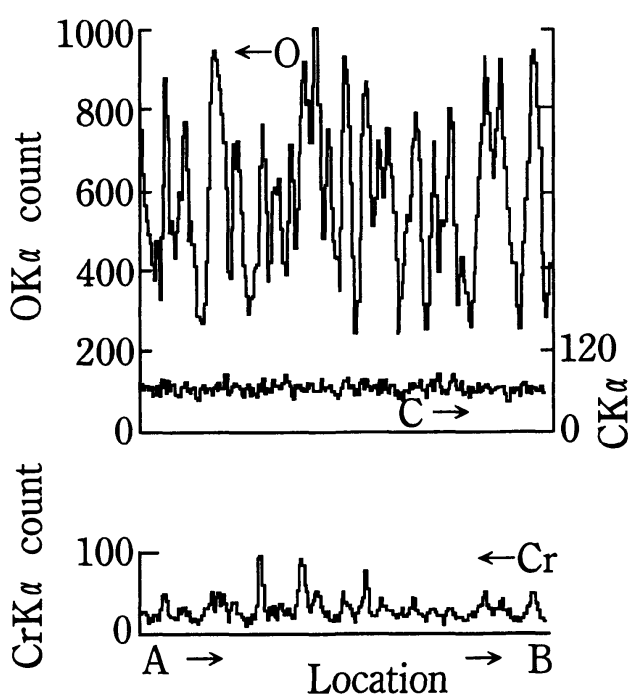

Fig. 3 Line analysis profiles of $\mathrm{Ti}, \mathrm{Si}, \mathrm{O}, \mathrm{C}, \mathrm{Fe}, \mathrm{Cr}$, and $\mathrm{Ca}$ along the line $\mathrm{AB}$ in the SE image of Fig. 2

quantitative evaluation, Fig. 3 shows line analysis profiles of titanium, silicon, oxygen, carbon, iron, chromium, and calcium along the line $\mathrm{AB}$ in the SE image of Fig. 2. From these profiles, it was found that the titanium content varied within about $10 \%$ of its maximum. The oxygen content, with a background of about 200 counts, varied remarkably in a range of about 200 to 1,000 counts, corresponding inversely to the distribution of titanium. In addition, iron and chromium were detected, nearly corresponding to the distribution of oxygen, though their contents were low. The iron was not an impurity included in the titanium, but a major component of the 18-8 stainless steel clipping band which was abraded together with the specimen; the distribution of iron corresponded closely to that of chromium. Nickel, which was not analyzed, could be detected together with the iron and the chromium. Calcium, which was distributed similarly to the other elements, originated from a filler component included in the embedding resin. We note here that silicon was detected not throughout but in a scattered distribution pattern in several isolated spots.

In order to escape the influence of the stainless steel band and the filler on the contamination, resin-attached specimens were abraded and analyzed. The hard reaction zone ${ }^{4}$ contaminated by the investment constituent elements was entirely removed by the abrading. Fig. 4 shows the results of the element analysis. The distributions of titanium and oxygen were qualitatively similar to those shown in Figs. 2 and 3 . It is particularly noted here that 
the distribution of silicon corresponded closely to that of oxygen, entirely different from the result shown in Fig. 3. However, no peculiar aspect was found in the distribution of carbon. Although the specimen was carbon-evaporated, the contaminant carbon, if it existed, ought to be distinguishable from the evaporated carbon. In data not shown here, carbon was significantly detected together with silicon and oxygen on a surface abraded with silicone rubber polishers according to established dental techniques.

In the SE image of Fig. 4, occasional patterns with dimensions of roughly 10 to $30 \mu \mathrm{m}$ were observed corresponding to the distribution of silicon or oxygen. In order to demonstrate thcse patterns more clearly, a specimen was set on the specimen stage at an angle of $60^{\circ}$ to the electron beam and SE images were taken. Fig. 5 shows one of these images, in which contaminant deposits are observed overall.

From the results shown in Figs. 1 to 5 , it is obvious that all the abraded surfaces were contaminated by silicon and oxygen. Iron, chromium and calcium rather than silicon contaminated titanium when they existed together with the abrasive. The surface abraded to $\# 600$ grit was qualitatively the same as that abraded to $\# 1,000$ grit.

\section{Comparison with gold alloy}

It is well known that the reaction zone of a titanium casting is hard due to its high content
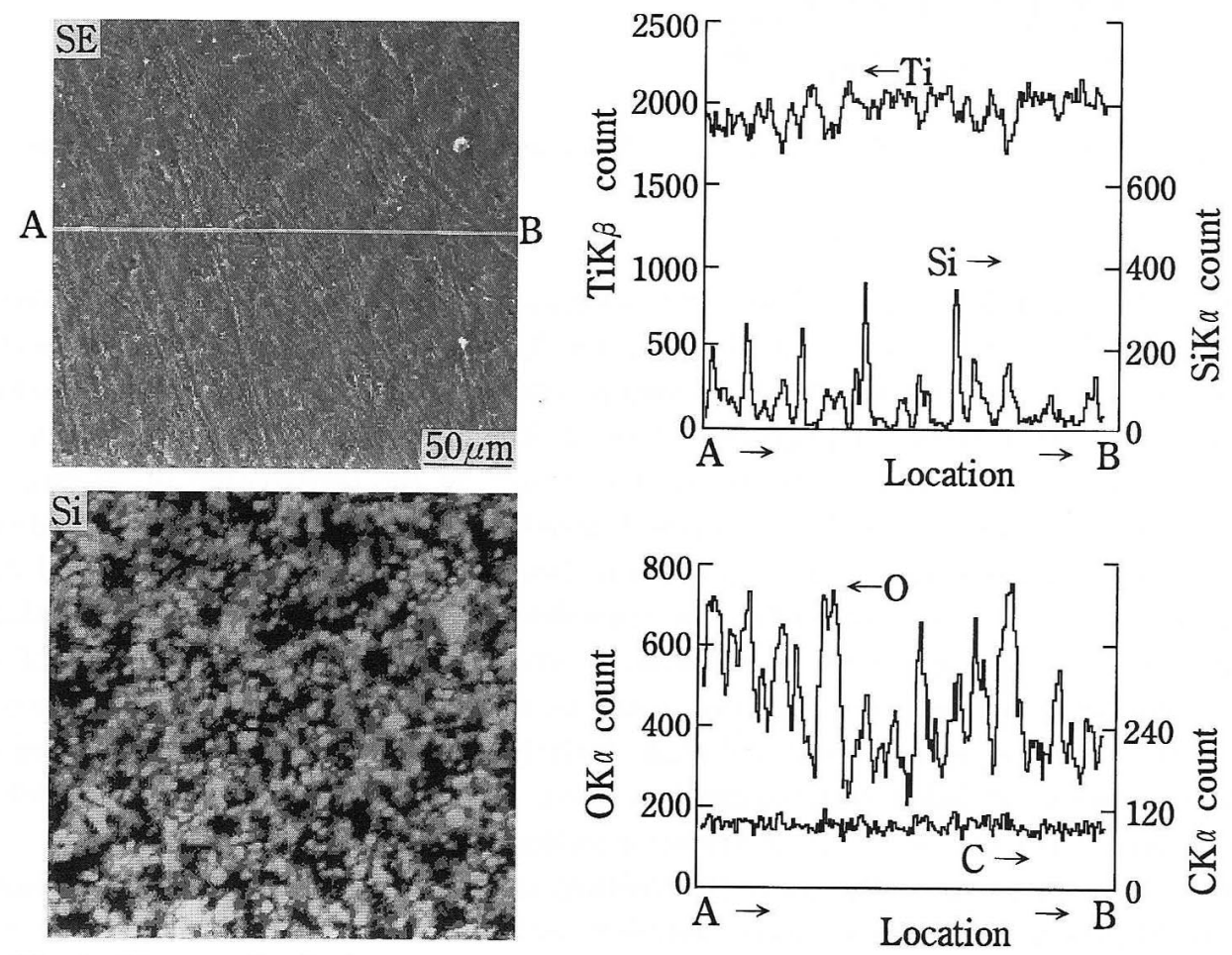

Fig. 4 Element distributions on an abraded Ti surface. The resin-attached specimen was abraded to \#1,000 grit. The line analysis profiles show the distributions of $\mathrm{Ti}, \mathrm{Si}, \mathrm{O}$, and $\mathrm{C}$ along the line $\mathrm{AB}$. 


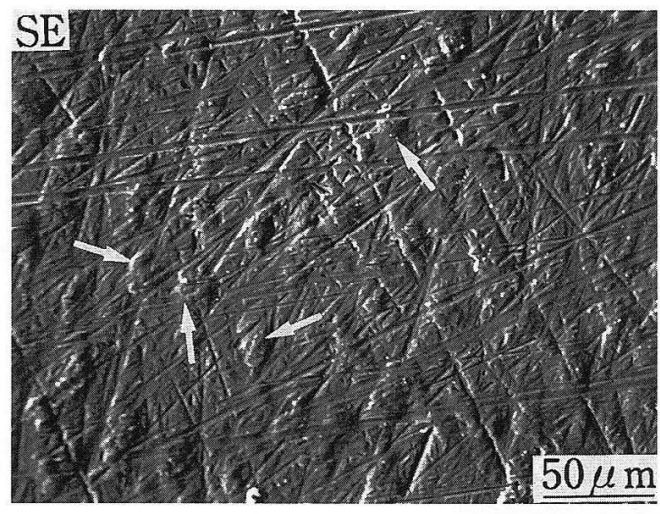

Fig. 5 An SE image showing contaminant deposits on an abraded Ti surface. Some deposits are indicated by arrows. The resin-attached specimen was abraded to \#600 grit. To make the image, the specimen was set at an angle of $60^{\circ}$ to the electron beam; the size scale is thus available only horizontally.

of solute oxygen ${ }^{4}$, exhibiting Hv values ranging from about 200 to 800 or more. On the other hand, the interior of the casting is relatively soft, with a low solute oxygen content, and $\mathrm{Hv}$ values between about 160 to $180^{6}$. In Fig. 1, however, the oxygen content in the reaction zone was apparently low compared with that in the interior of the casting. This means that the hard reaction zone was scarcely contaminated. Similarly, the work-hardened stainless steel clipping band, which was abraded together with titanium, was not contaminated by titanium, oxygen, silicon, calcium, or carbon (data not shown). These facts suggest that the contamination may be related to the hardness of the specimen, because abrasive grits may be embedded in the surface if the specimen is soft or ductile.

To test this hypothesis, another examination was performed using a type I dental casting gold alloy (55 to $90 \mathrm{Hv}$, ADAS \#5). Fig. 6 shows the element distributions on the surface abraded to \#600 grit. As described in Fig. 3, silicon was detected not overall but occasionally, suggesting the possibility that abrasive grits might be embedded in the gold alloy surface. Although the background of oxygen was rather high due to the existence of gold, the distribution of oxygen was obviously different from that shown in Figs. 1 to 4 . This means that the contamination of titanium was related to its reactivity as well as its hardness.

\section{Chemical bond state analysis}

To determine the properties of the contaminant deposits, chemical bond state analysis was performed focusing on silicon and oxygen. The results shown in Fig. 7 indicate that the chemical bond state of the silicon was similar to that of silicon carbide or a titanium silicide ${ }^{4)}$, neither silicon oxide nor silicon. The state of the oxygen was close to that of solute oxygen in titanium. 


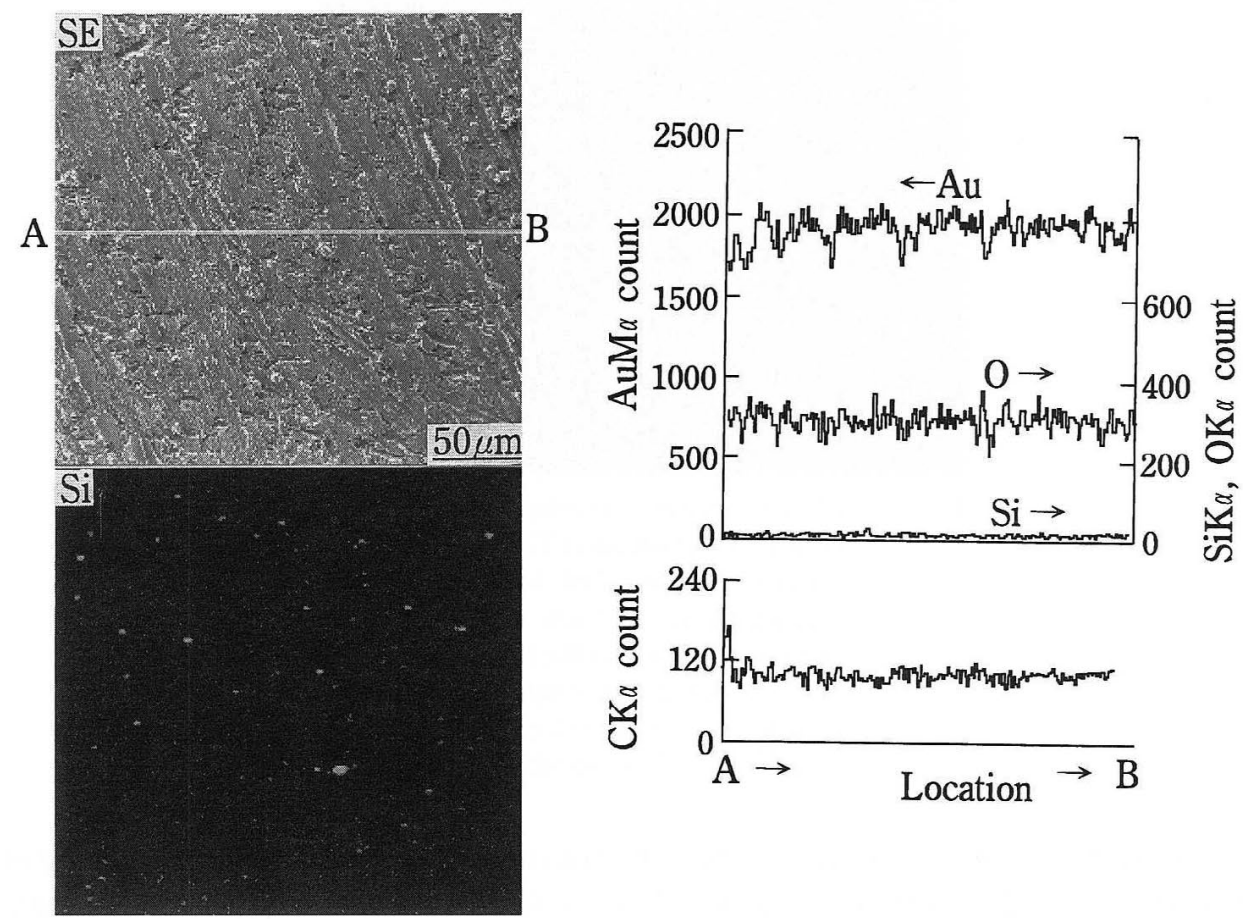

Fig. 6 Element distributions on an abraded type I gold alloy. The resin-embedded specimen was abraded to $\# 600$ grit. The line analysis profiles show the distributions of $\mathrm{Au}, \mathrm{O}$, Si, and $\mathrm{C}$ along the line $\mathrm{AB}$.

\section{$X$-ray diffraction analysis}

In order to identify the contaminant deposits, the abraded surface was analyzed by $\mathrm{X}$-ray diffraction. Fig. 8 shows a chart of diffraction by the Bragg-Brentano method. In Table 1, peaks obtained in Fig. 8 were compared with standard peaks of the following substances: $\alpha$ -titanium, titanium carbide, silicon carbide, silicon, graphite, and titanium silicides such as $\mathrm{Ti}_{5} \mathrm{Si}_{4}, \mathrm{Ti}_{5} \mathrm{Si}_{3}$, TiSi and $\mathrm{TiSi}_{2}$. Except for three peaks of very slight intensity (arrow heads in Fig. 8), all the major peaks (solid circles in Fig. 8) were identified as $\alpha$-titanium with a confidence coefficient of 865, as shown in Table 1. However, the confidence coefficient for titanium carbide (open circles in Fig. 8) was 225 and those for the other substances were lower. In other words, the three unknown peaks could not be identified clearly, suggesting that the major portion of the contaminant deposit might be amorphous or very thin.

The present study concluded that the surface contamination of titanium probably resulted from a reaction with abrasive materials. It is still not known whether the contaminant oxygen originated from the cooling water or from the adhesive which holds the abrasive grit to the paper.

\section{Influence of surface contamination}

The abraded surface reflected light irregularly, exhibiting a blackened shade (not shown 

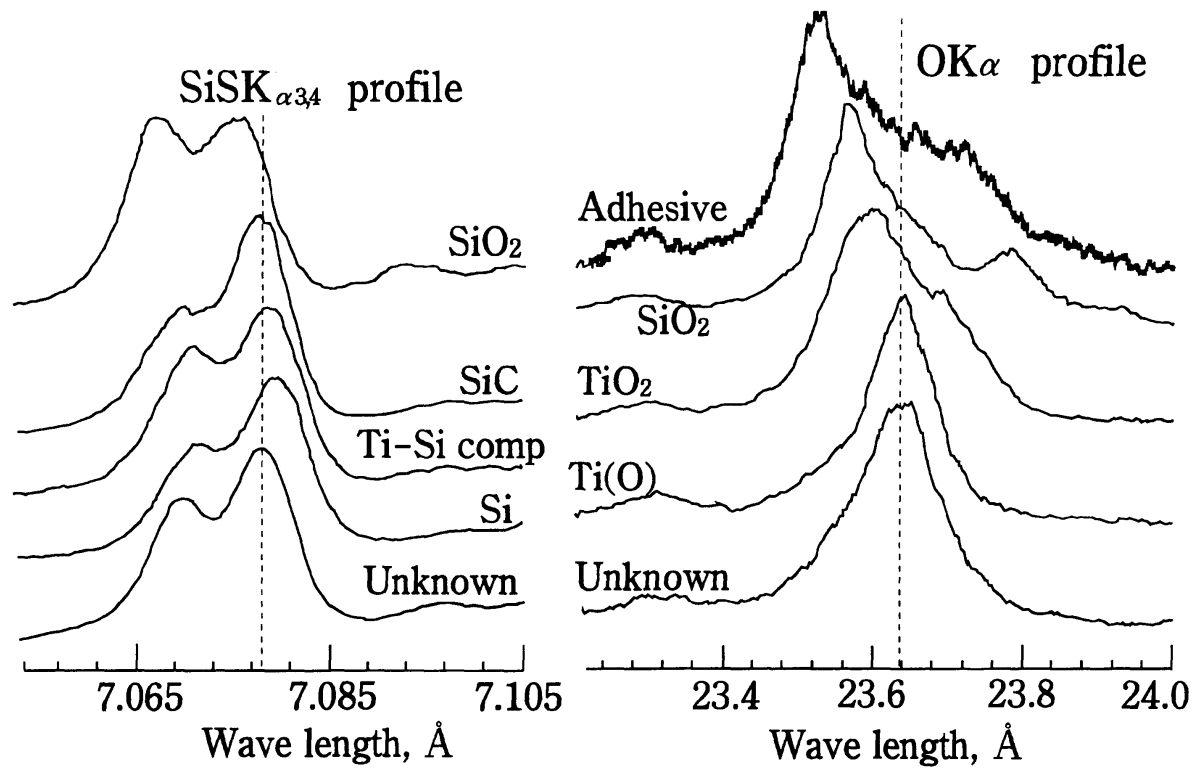

Fig. 7 Chemical bond states of $\mathrm{Si}$ and $\mathrm{O}$ on an abraded Ti surface. The profiles of Si satellite $\mathrm{K}_{a 3,4}$ and $\mathrm{O} \mathrm{K}_{a}$ spectra of the contaminant were compared with those of standard substances. "Ti-Si comp" represents a net-shape and titanium silicide-like phase existing in the reaction zone of a titanium casting. "Ti(O)" is solute oxygen in the $\alpha$ -case of a titanium casting.

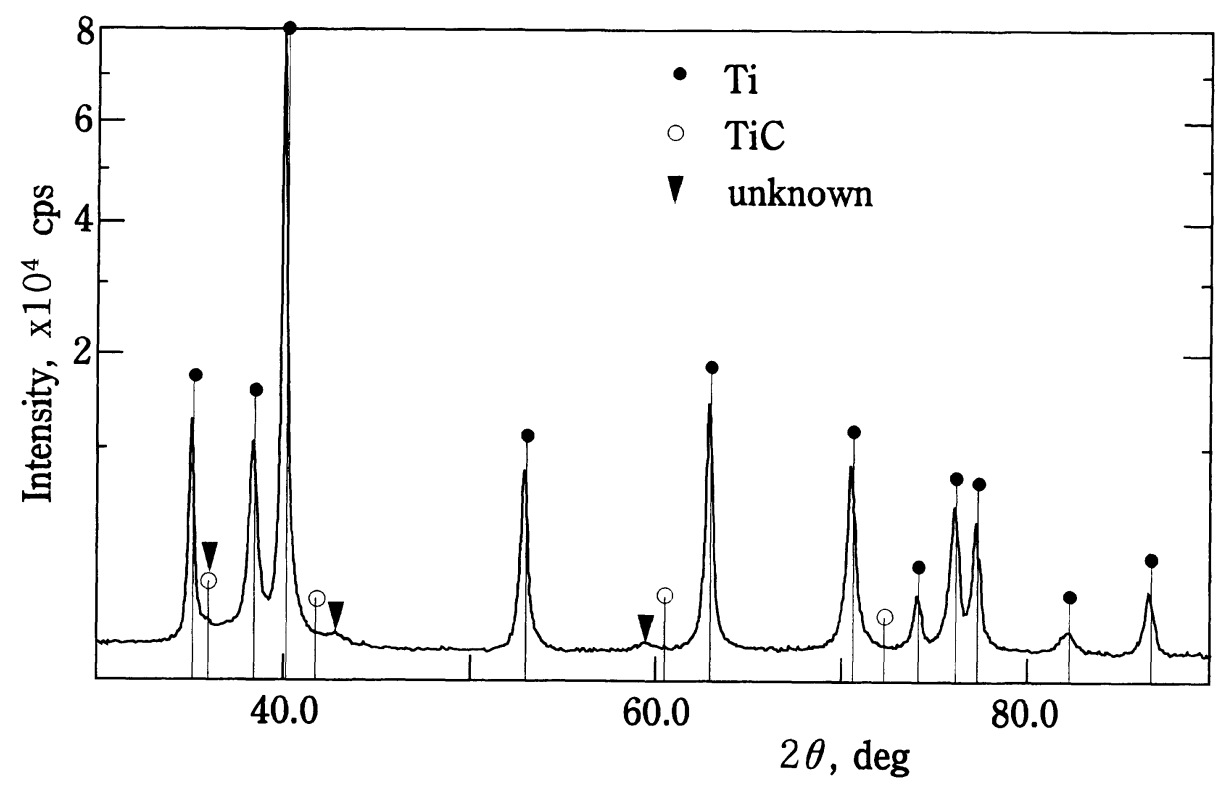

Fig. 8 An X-ray diffraction chart of an abraded Ti surface (Bragg-Brentano method). The resin-attached specimen was abraded to \#1,000 grit. Refer to Table 1 for "Ti" and "TiC" 
Table 1 Retrieval of peaks obtained in Fig. 8

\begin{tabular}{c|l|c|l|r|r|r}
\hline No. & $\begin{array}{c}\text { Card No. } \\
\text { Ref. mark }\end{array}$ & $\begin{array}{c}\text { Chemical } \\
\text { formula }\end{array}$ & Mineral name & N1 & N2 & Co \\
\hline 1 & $44-1294 *$ & $\mathrm{Ti}$ & & 11 & 10 & 865 \\
2 & $32-1383 *$ & $\mathrm{TiC}$ & Khamrabaevite, syn & 5 & 2 & 225 \\
3 & $44-1288 \mathrm{C}$ & $\mathrm{Ti}$ & & 4 & 1 & 194 \\
4 & $22-1317 \mathrm{I}$ & $\mathrm{SiC}$ & Moissanite-4H, syn & 11 & 3 & 179 \\
5 & $35-1158$ & $\mathrm{Si}$ & & 5 & 1 & 173 \\
6 & $29-1131 *$ & $\mathrm{SiC}$ & Moissanite-6H, syn & 9 & 2 & 145 \\
7 & $29-1126 \mathrm{C}$ & $\mathrm{SiC}$ & Moissanite-2H, syn & 11 & 2 & 115 \\
\hline
\end{tabular}

N1: Number of peaks of a possible substance

N2: Number of obtained peaks which coincided with those of the possible substance

Co : Confidence coefficient

Peaks obtained in Fig. 8 were compared with those of the following possible substances; $\alpha$ -

$\mathrm{Ti}, \mathrm{TiC}, \mathrm{SiC}, \mathrm{Si}$, graphite, and titanium silicides such as $\mathrm{Ti}_{5} \mathrm{Si}_{4}, \mathrm{Ti}_{5} \mathrm{Si}_{3}$, TiSi and $\mathrm{TiSi}_{2}$.

Substances with confidence coefficients lower than 100 are omitted from this table.

here). Polishing with an aqueous slurry of $\mathrm{Fe}_{2} \mathrm{O}_{3}$ powder removed the contaminant entirely and provided a smooth and glossy surface (not shown).

As mentioned previously (Fig. 7), the contaminant oxygen was solute in titanium, suggesting the possibility that the oxygen may harden the abraded surface. The Vickers hardness test was performed at forty points on the abraded surface. Hardness numbers varied between 187 and 285, and an average of 228 was obtained with a standard deviation of 24.6. The hardness could not readily be related quantitatively to the contaminant oxygen content, because the size of the Vickers hardness test indentation was comparable to that of the contaminant deposit (Fig. 5). However, the variation of hardness appeared to correspond to the distribution of contaminant oxygen. As with the casting of JIS class 2 titanium, hardness numbers were in a range of about 160 to $180^{6}$, not at the reaction zone but in the interior. It is clear that the contaminant oxygen increased the hardness of the abraded surface. In spite of the very high oxygen content, however, the hardness did not reach that of the reaction zone. This was confirmed by a comparison of four Vickers hardness indentations along the line $\mathrm{AB}$ in the SE image of Fig. 1. The reason may be that the contaminant oxygen did not diffuse into the interior.

Surface contamination affects the esthetics of restorations. Furthermore, it may influence negatively titanium's bio-compatibility and resistance to corrosion. More efficient finishing techniques are needed to widen the use of titanium in dentistry.

\section{CONCLUSION}

In spite of water cooling and slow-speed abrading, titanium surfaces were obviously contaminated. Contaminant deposits with dimensions ranging from about 10 to $30 \mu \mathrm{m}$ occurred throughout the surfaces. In these deposits, the titanium content was apparently reduced by about $10 \%$, being replaced by silicon and oxygen. Iron, chromium and calcium rather than silicon contaminated the surfaces when these elements existed together with the abrasive. Distributions of these elements corresponded closely to that of oxygen. The 
chemical bond state of the silicon was similar to that of silicon carbide or a titanium silicide. The oxygen was solute in titanium, which increased the hardness of the abraded surface. $\mathrm{X}$ -ray diffraction suggested that the contaminant deposit was amorphous or very thin. The contamination of titanium, although related also to the hardness, resulted primarily from a reaction with abrasive materials. Such contamination could influence negatively titanium's resistance to corrosion and its bio-compatibility.

\section{REFERENCES}

1) Miyakawa, O., Watanabe, K., Okawa, S., Nakano, S., Shiokawa, N., Kobayashi, M. and Tamura, H. : Grinding of titanium, Part 1 Commercial and experimental wheels made of silicon carbide abrasives, J J Dent Mater 9 (1): 30-41, 1990. (in Japanese)

2) Miyakawa, O., Watanabe, K., Okawa, S., Nakano, S., Shiokawa, N., Kobayashi, M. and Tamura, H. : Grinding of titanium, Part 2 Commercial vitrified wheels made of alumina abrasives, $J J$ Dent Mater 9 (1) : 42-52, 1990. (in Japanese)

3) Japan Industrial Standards $\mathrm{H} 4600$

4) Miyakawa, O., Watanabe,K., Okawa, S., Nakano, S., Kobayashi, M. and Shiokawa, N.: Layered structure of cast titanium surface, Dent Mater J 8 (2): 175-185, 1989.

5) Miyakawa, O., Watanabe,K., Okawa, S., Nakano, S., Honma, H., Kobayashi, M. and Shiokawa, N. : Skin holes of titanium casting, Dent Mater J 12 (2) : 171-181, 1993.

6) Ida, K., Togaya, T., Tsutsumi, S. and Takeuchi, M. : Effect of magnesia investments in the dental casting of pure titanium or titanium alloys, Dent Mater J 1 (1): 8-21, 1982. 


\title{
本号揭載論文の和文抄録
}

\author{
接着性モノマーの NMR 研究 \\ 5 -メタクリロイルアミノサリチル酸の ${ }^{13} \mathrm{C}-\mathrm{NMR}$ スペクトルの \\ 完全帰属と分子幾何学研究 \\ 伊藤 茂, 藤沢盛一郎 ${ }^{1}$ \\ 東京医科歯科大学医用器材研究所化学部門 \\ ${ }^{1}$ 明海大学歯学部口腔診断学講座
}

6 個の四級炭素をもつ 5-メタクリロイルアミノサリ チル酸 (MASA) の ${ }^{13} \mathrm{C}-\mathrm{NMR}$ スペクトルをDEPT スペ クトルならびに $\mathrm{CH}-\operatorname{cosy}$ や $\mathrm{HMBC}$ 等の 2 次元 $\mathrm{NMR}$ スペクトルの解析により完全帰属した. MASA の ${ }^{13} \mathrm{C}$ -NMR 化学シフト值のコンピュータプログラムによる
経験的な予測は C 1 と 2 '位 $\mathrm{CH}_{3}$ の值を除いて観測値 と比較的よく一致した. 2 次元 NMR を用いた核オー パーハウザー効果の測定・解析と分子軌道計算結果の比 較により MASA の側鎖部分の立体配置は極性および非 極性雾囲気下において異なることが示唆された。

\section{チタン研磨面の污染}

宮川 修, 渡辺孝一, 大川成剛, 金谷 貢, 中野周二, 小林正義 ${ }^{1}$

新潟大学歯学部歯科理工学講座

1新潟大学分析センターEMX 室

チタン研磨面の污染について検討した，研磨装置によ り, $\mathrm{SiC}$ 耐水研磨紙を用いて水冷下で研磨し, 研磨面の元 素分析, X 線回折, 硬さ測定を行った. 10〜 30 $\mu \mathrm{m}$ の大 きさの污染物様のものが研磨面全体に観察された. そこ での Ti の見かけの濃度は約 $10 \%$ 低下し, Si とOの濃度 が高かった: $\mathrm{Si}$ の結合状態は SiC または Ti-Si 化合物の
それに似ていた。 $\mathrm{O}$ は固溶酸素として存在し，研磨面を 硬化させた. 污染物は非晶質か, あるいは非常に薄いこ とが示唆された.このようなチタンの污染は, その硬さ とも無関係ではないが，研磨材との何らかの反応による と考えられる.

モルモットを用いた各種デンティンプライマーによる接触性皮膚炎の検討 勝野和之, 真鍋厚史, 伊藤和雄, 中村吉宏, 和久本貞男, 久光 久, 吉田武美 ${ }^{1}$

昭和大学歯学部歯科保存学第 2 講座 ${ }^{1}$ 昭和大学楽学部毒物学教室

コンポジットレジンの象牙質窩壁適合性を改善する目 的で適用されるデンティンプライマーやボンディング材
の多くは, 2-hydroxyethyl methacrylate (HEMA) が配 合されている.しかしながら, 我々はこの HEMA を長期 